\title{
RECENZJE
}

\section{Frontinus, O akweduktach Miasta Rzymu. Traktaty miernicze, pod red. A. Pikulskiej-Radomskiej i K. TAdajCzyka, Wydawnictwo Uniwersytetu Łódzkiego, Łódź 2017, ss. 150}

Ostatnie lata przyniosły w polskiej romanistyce wyraźny wzrost zainteresowania prawem publicznym. Przejawem tego są nie tylko liczne publikacje, zarówno w postaci monografii, jak i artykułów naukowych, lecz także tłumaczenia antycznych źródeł dotyczących życia i prawa publicznego.

Wraz z początkiem 2018 roku na rynku księgarskim ukazała się interesująca pozycja książkowa pod redakcją prof. Anny Pikulskiej-Radomskiej i dr. Konrada Tadajczyka Frontinus. O akweduktach Miasta Rzymu. Traktaty miernicze. Jak sugeruje sam tytuł, publikacja nie jest jednorodna, ale obejmuje kilka antycznych dzieł o tematyce z zakresu urbanistyki i planowania przestrzennego, geodezji oraz inżynierii wodnej. Jednak głównym motorem sprawczym do jej powstania było dzieło De aquaeductu urbis Romae autorstwa Sextusa Iuliusa Frontinusa, który w czasach panowania cesarza Nerwy (96-98 n.e.) piastował urząd curator aquarum. Traktat, według przewidywań Frontinusa, miał przynieść pożytek jego następcy, a także przyczynić się do ustalenia wypracowanych przez niego zasad (Front., De aq. 3,3). Jak się jednak okazało, udało się mu stworzyć dzieło ponadczasowe, które miało stanowić wskazówkę nie tylko dla jego bezpośrednich następców, lecz także dla kolejnych pokoleń. Obecnie De aquaeductu urbis Romae to przede wszystkim nieocenione źródło poznania antycznej inżynierii oraz przepisów prawa regulujących zasady zaopatrywania miasta w wodę, które na przestrzeni lat doczekało się wielu opracowań i tłumaczeń na języki narodowe. W 1961 r. traktat został przetłumaczony na język polski, a dokonał tego 
prof. Cezary Kunderewicz. Swój przekład opatrzył ponadto wstępem i komentarzem. Niestety, jak słusznie zauważają autorzy recenzowanej publikacji, dzieło C. Kunderewicza jest obecnie praktycznie niedostępne. Tym bardziej więc na uznanie zasługuje ich pomysł na reedycję tłumaczenia dzieła Frontinusa. Dodatkową zaletą książki A. Pikulskiej-Radomskiej i K. Tadajczyka jest wydanie w ramach jednego tomu, obok De aquaeductu urbis Romae przekładów także innych traktatów mierniczych autorstwa Frontinusa, to jest De agrorum qualitate, De arte mensoria, De controversiis i De limitibus, co, jak sami podkreślają, będzie pomocne dla „poznania kultury technicznej Rzymu z okresu pryncypatu" (s. 9).

Recenzowana publikacja liczy 150 stron. Rozpoczyna się od Wykazu skrótów. Zaraz po nim następuje Przedmowa (s. 9-10), w której autorzy bardzo ogólnie zapoznają czytelnika z postacią Sextusa Iuliusa Frontinusa, a następnie wyjaśniają motywy swojego przedsięwzięcia.

Na stronach od 11 do 104 zamieszczony został pełny tekst przekładu De aquaeductu urbis Romae autorstwa C. Kunderewicza wraz ze Wstępem i komentarzem. Ten ostatni ujęto w formie przypisów dolnych.

Kolejny rozdział, zatytułowany Frontinus i środowisko rzymskich mierniczych (s. 105-123) jest autorstwa A. Pikulskiej-Radomskiej. Został on podzielony na paragrafy, a rozpoczyna się od syntetycznie przedstawionej historii profesji mierniczego w Rzymie oraz krótkiej charakterystyki przebiegu pracy zawodowej Frontinusa (s. 105-106). W paragrafie Traktaty miernicze (s. 107-108) autorka już w pierwszych wersach podkreśliła rolę, jaką mierniczowie odgrywali w życiu społecznym. Niestety, jak zauważa, przeprowadzenie dokładnych badań na temat ich działalności, a zwłaszcza tworzonych przez nich pism jest dziś bardzo trudne, głównie ze względu na niekompletność tychże oraz liczne zmiany, jakim poddawano je przy okazji prac redakcyjnych w VI w. n.e. Spowodowały one bowiem, że do naszych czasów pisma te „zachowały się w postaci poważnie zniekształconej, czasem wręcz streszczone” (s. 107).

W paragrafie Praktyka miernicza: instrumenty miernicze (s. 108-111) autorka skupiła się na kwestiach terminologicznych, usiłując w szczególności ustalić, jakich określeń używano w odniesieniu do mierniczych 
oraz ich narzędzi. Za najbardziej typowy, wręcz symboliczny dla rzymskich mierniczych instrument uznała gromę (s. 109).

Następnie, na stronach 111-115 omówiona została Praktyka miernicza: wytyczanie granic. W związku z tym, że pomiarów i podziałów związanych z zakładaniem miast, kolonii czy obozów wojskowych dokonywano przy zastosowaniu limitatio, na tej właśnie procedurze skupiono główną uwagę.

Paragraf Praktyka miernicza: sporządzanie map i ustawianie znaków granicznych (s. 115-117) poświęcony został problematyce dotyczącej sporządzania map oraz roli tychże. Wyjaśniono także kwestie terminologiczne dotyczące gruntów, tj. agri limitati i agri arcifini.

W kolejnym paragrafie autorka skupiła się na ciekawej i istotnej kwestii, będącej zresztą następstwem istnienia granic, to jest na związanych z nimi sporach i regulujących je zasadach prawnych. Tak też został zatytułowany ów paragraf - Spory graniczne: eksperci i arbitrzy (s. 117-121). Przede wszystkim poruszona została w nim problematyka dotycząca określania przebiegu granic (kontrowersje de fine) oraz ustalania tytułu władztwa nad gruntem (kontrowersje de loco), co ściśle wiązało się z doborem odpowiednich środków procesowych, wymienionych przez autorkę. Oprócz zadań arbitrów, którzy jako pierwsi powołani byli do rozstrzygania sporów granicznych, nieco uwagi prof. A. Pikulska-Radomska poświęciła także roli odgrywanej w takich przypadkach przez mierniczych.

W ostatnim paragrafie noszącym tytuł Formacja intelektualna mierniczych (s. 121-123) autorka skupiła się na udzieleniu odpowiedzi na pytanie o ogólne wykształcenie mierniczych. Wyniki jej badań mogą wydać się zaskakujące, choć tylko pozytywnie. Okazuje się bowiem, że oprócz stricte fachowej wiedzy, byli oni także obeznani w kwestiach prawnych, a przynajmniej posługiwali się terminologią prawniczą. Mieli też rozeznanie w zakresie statusu różnych gruntów i charakteru obciążeń finansowych związanych z władaniem nimi. Nie obca była im ponadto wiedza z zakresu astronomii, geometrii przestrzennej i kartografii, a nawet kosmologii.

Rozdział o Frontinusie i środowisku rzymskich mierniczych kończy się krótkim, acz treściwym podsumowaniem zawierającym zachętę do 
lektury pism rzymskich mierniczych, które „napisane językiem prostym w sensie formy, zawierają bogactwo informacji - zarówno czysto fachowych, mierniczych, jak i obyczajowych" (s. 123).

Recenzowaną publikację wieńczy rozdział Traktaty miernicze (s. 125-143) obejmujący przekład poszczególnych poświęconych temu zagadnieniu prac Frontinusa, a więc: O kategoriach gruntów (s. 127-129), O sporach (s. 130-135), O liniach działowych (s. 136-139) oraz O Sztuce mierniczej (s. 140-143).

$\mathrm{Na}$ ostatnich stronach czytelnik może znaleźć Indeks imion i nazw własnych (s. 145-146), Indeks nazw geograficznych (s. 147-148) i Skorowidz terminów technicznych (s. 149). Zważywszy na specyfikę tematyki prezentowanej w publikacji, zamieszczenie wymienionych indeksów było trafnym posunięciem, tym bardziej że praca kierowana jest nie tylko do romanistów, historyków starożytności czy filologów, a więc osób znających język łaciński, ale również do osób parających się zawodami niewymagającymi jego znajomości, jak choćby do inżynierów czy po prostu miłośników świata antycznego.

Recenzowana publikacja doskonale wpisuje się w ożywiony w ostatnich latach nurt badań nad rzymskim prawem publicznym wnosząc w nie istotny wkład. Na uznanie zasługuje już sam pomysł reedycji polskiego przekładu De aquaeductu urbis Romae autorstwa Cezarego Kunderewicza, w czasach obecnych niebywale trudny do zdobycia. Dużą zaletą publikacji jest dołączenie tłumaczeń traktatów mierniczych Sextusa Iuliusa Frontinusa oraz artykułu poświęconego mierniczym. Dopełniają one obraz tego zawodu i pozwalają dostrzec znaczenie działalności Frontinusa w dziedzinie administracji publicznej oraz jego traktatu poświęconego wodociągom. 